\title{
Closing address
}

\author{
OTto KinNE \\ Biologische Anstalt Helgoland, Zentrale, Hamburg 50
}

Dear Colleagues and Friends!

The First European Symposium on Marine Biology has come to an end. What remains to be done is to express my gratitude to all of you. You all have helped to make this first symposium what it was intended to be: a suitable basis for the presentation of new scientific information, for discussions, and for the establishment of new, as well as the deepening of already existing, personal contacts.

I am particularly glad that it was possible to form a committee which will ensure the continuity of the series of European symposia on marine biology, the "Committee for European Marine Biology Symposia" (CEMBS). Special thanks go to Dr. H. BARNES who has accepted to act as the first president of this committee. In order to provide for plasticity and "eternal youth", it is felt that the president and committee members should serve only for 3 year terms; while the president may, in exceptional cases, be re-elected for one additional period, commitree members should not serve longer than 3 consecutive years. These and related points ought to be discussed in more detail during the next symposia in Bergen (Norway) and Arcachon (France).

It is a great pleasure for me to thank our three introductory speakers: Drs. Barnes, Riedl and Margalef. In their excellent lectures they have more than adequately introduced the three main topics of our symposium. I would further like to thank all chairmen (including those responsible for the "splash party" performances in the swimming pool), all speakers and discussion participants.

Congratulations to the Scandinavian swimming team for winning the "submarine prize" of the First European Symposium on Marine Biology. Hopefully this prize will be brought to the next symposium in Bergen; we shall then see who will be the new winner. I am sorry that the captain of the team, Dr. B.-O. JANsson, developed, at the beginning of the race, such an amount of thrust that he collided with the hard bottom community of the swimming pool. What makes matters even worse is that the collision occurred at a part of his body which is assumed to be the most important one of any scientist: his head. We surely hope that he will recover fast.

In the list of acknowledgements, I must not forget the U.S. Office of Naval Research, Branch Office, London (Liaison Scientist: Dr. J. D. CostLow Jr.) which has made it possible to retain the translation services during this last morning's session. 
We also owe gratitude to the ladies and gentlemen who have been working busily, but hidden in those two big "aquarium tanks", for a very good translation.

Last, but not least, I should like to thank scientists, technicians, and administrative personnel of the Biologische Anstalt Helgoland for their enthusiastic support. During the many months of preparing this symposium and during these last few days, they have done their utmost; I am sure some of them have lost weight.

Looking into the future, it is my sincere hope that the European Marine Biology Symposia will prove to be a useful instrument for bringing together marine biologists in annual meetings in order to discuss new scientific results and to enjoy the stimulations which result from personal contacts. Thanks to all of you and a good trip home! I herewith close the First European Symposium on Marine Biology. 